\title{
Planned Disregard in Consumer Relations: A Proposition to Redress Consumer's Lost Time
}

\author{
Laís Bergstein \\ Pontifical Catholic University of Paraná, Brazil \\ Federal University of Rio Grande do University, Brazil
}

\begin{abstract}
Time exerts multiple influences on consumer relations since it is a triggering factor for several legal obligations, especially in long-term contractual bounds. The valuation of time as an essential and limited resource has emerged in the context of post-modernity with the formation of a new consciousness about the effects that its passage exerts on people. In Brazil, especially since 2009, several judicial decisions recognized the time lost by consumers trying to solve conflicts with suppliers as a special kind of moral damage and guaranteed the right to redress. However, many other consumers in similar situations had the same right denied in courts, mostly due to the lack of criteria to compensate the time lost due to acts attributable to suppliers. In this context, the research proposes a double criteria to pursue the adequate compensation for the time lost by consumer through the evaluation of supplier's conducts. The study makes a distinction of consumer's time and supplier's time and defines the commercial practice entitled "planned disregard" as the abusive devaluation of time and the efforts made by consumers to achieve a successful conclusion to consumer contracts, mostly due to the lack of investments in efficient customer care services. This type of commercial practice violates the limits of good faith and represents an excessive advantage for the supplier, breaking the legal balance that the law establishes in consumer relations. The paper also approaches the legal duties of effective prevention and full redress of damages in Brazilian consumer law which are the legal tools to compensate the damage due to the loss of time suffered by consumers. Finally, it suggests how the members of the national consumer protection system, such as the regulatory agencies, civil entities, and the judiciary may contribute with structural processes to the prevention of undue loss of consumer time.
\end{abstract}

Keywords: consumer time, planned disregard, damage due to time lost, full redress, structural processes

\section{Introduction}

Time exerts multiple influences on consumer relations, since it is a triggering factor for several legal obligations, especially in long-term contractual binds. The valuation of time as an essential and limited resource has emerged in the context of post-modernity with the formation of a new consciousness about the effects that its passage exerts on people.

In Brazilian courts, the compensation for time lost by consumers trying to resolve problems caused by suppliers is very controversial. Especially since 2009, several judicial decisions recognized the time lost by

Laís Bergstein, Ph.D., Department of Private Law, Pontifical Catholic University of Paraná, Brazil; Federal University of Rio Grande do University, Brazil. The main ideas presented in this article were discussed earlier at the 17th Conference of the International Consumer Law Association, hosted by Professor James P. Nehf at the University of Indiana's Robert H. McKinney Law School. The author sincerely thanks all the generous contributions offered by the participating researchers at the time. 
consumers trying to solve conflicts with suppliers as a special kind of moral damage and guaranteed the right to redress. On the other hand, many consumers in similar situations had the same right denied in courts, mostly due to the lack of criteria for compensation of the time lost due to acts attributable to suppliers.

In this context, the present research proposes a double criteria to pursue the adequate compensation for the time lost by consumer through the evaluation of supplier's conduct. The study makes a distinction of consumer time and supplier's time and defines the "planned disregard" as the abusive devaluation of time and the efforts made by consumers to achieve a successful conclusion to consumer contracts, usually caused by the lack of investments in efficient customer care services. This commercial practice-planned disregard-exceeds the limits of good faith and represents an excessive advantage for the supplier, breaking the legal balance that the law establishes in consumer relations.

The paper approaches the legal duties of effective prevention and full redress of damages in Brazilian consumer law which are the legal tools to compensate the damage due to the loss of time suffered by consumers. Finally, it suggests how the members of the national consumer protection system, such as the regulatory agencies, civil entities, and the judiciary may contribute with structural processes to the prevention of undue loss of consumer time.

\section{Consumer's Time and Supplier's Time}

Aristotle and Newton believed in absolute time. They believed that one can measure the time interval between two events in such a way that the result will be the same in any measurement, if a precise clock is used. Their belief is the common sense today that time is independent and completely separated from space (Hawking, 1992).

However, the science with the technological support made significant progress in the knowledge on this subject. The idea that there was a universal quantity called time that all clocks would measure equally has long been abandoned. Several experiments have already confirmed that the time measured by two people will only coincide if they are at rest in relation to each other, but not in accelerated motion. It is exactly what Albert Einstein demonstrated in his revolutionary theory of relativity (Hawking, 2002).

Distance and time gained new contours due to the technological advances. The railroad constructions, for example, were large historical landmarks. In the decades leading up to the completion of the Central Pacific Railroad, linking California to Utah (USA), the time of travel on this route was six to seven strenuous weeks, permeated by crashes and many other challenges. With the completion of the transcontinental railroad, the 3,000 kilometers were comfortably trafficked in less than a week (Solnit, 2004).

At some point, horses were the fastest mean of transport, just as pigeons were the fastest mean of communication. Technology changed our relation with time. Now, as David Frisch (2012) pointed out, "our personal time is the ultimate scarce resource and should not be squandered without receiving something of value (such as money or enjoyment) in return" (pp. 757-801).

Time, in general, is not the object of constant concern or reflection of human beings. Charles Lamb (2008) once said "nothing puzzles me more than time and space; and yet nothing puzzles me less, for I never think about them" (p. 240). This is a common paradox. Time is human being's most valuable possession; it is actually one's life. Frequently, however, the concern with time lost only arises from the forced perception of its scarcity, as the result of a dramatic event, such as illness or even the death of a loved one. Time then becomes the protagonist of the life affected-the person concentrates on how much of it is still left and how not to waste 
it. As these doubts gain focus, the value that the person ascends to his/her own time gradually increases.

In consumer relations, the passage of time should be favorable to the consumer, but mass society often brings out the fact that the time lost by the other is ignored, considered an annoyance that must be tolerated. Certainly not. Time has the utmost importance for the human being, its loss is legally valuable and economically quantifiable (Marques \& Bergstein, 2018), and consumer's time composes the damages reportable in the legal relations of consumption (Marques \& Miragem, 2014) as well as the psychological damages and (totally avoidable) setbacks of our contemporary society (Ghersi, 2000).

To redress consumer lost time means to compensate financially for the loss of the "opportunity to engage in an alternative activity; it is in this opportunistic sense that time has been lost", in the perspective of

individuals who, for one reason or another, are forced to spend their personal or leisure time in undesirable ways, and for which no lost economic opportunity can be readily identified. Claims of this sort can be described as "lost personal time". (Frisch, 2012, pp. 757-801)

On the other hand, supplier's time relates to investments. As Claudia Lima Marques (2011) noted,

the "loss" or deviation of the supplier's time is valued as a cost or economic burden: to inform the consumer in detail is "cost", to cooperate with the consumer during the execution of the contracts is "professional burden", to develop a post-contractual system that avoids damages to the consumer, by organizing an effective customer care service and a network of capillary technical assistance, is “cost". (pp. 11-12)

In this context, an important distinction is made: The time of the human being has an existential value, corresponds to one's life, while the time of the legal entity (supplier) represents, as a rule, the capital invested in the productive activity. Both sides are undeniably relevant, but in consumer relations, the consumer's time, the time of the vulnerable contractor, is the one that invokes and deserves legal guardianship.

Consequently, it is not possible to qualify in the same way or to attribute the same legal value to the time lost by the natural person and the time lost by the supplier in the direct exercise of its professional activity. Nowadays, it is unthinkable to wait the length of a horseback trip for a product or to trust a message to a pigeon. The technology gave us a new perspective of reasonable time for the performance of the daily tasks and that is one of the reasons suppliers must be encouraged and compelled to respect and protect consumer's time by investing in effective prevention for damages and customer care services.

\section{The Consumer Right to Redress for Lost Time}

The Brazilian Consumer Defense and Protection Code (Law No. 8.078/1990-CDC) establishes as a principle of the National Consumer Policy to incentive suppliers to create efficient ways to control the quality and the safety of products and services (Article 4, V, CDC). It seeks to ensure consumers respect health and safety, protect their economic interests, and improve their quality of life as well as transparency and harmony of consumer relations. In addition, Article 6th, VI of the CDC establishes as basic consumer rights, the effective prevention and reparation for pecuniary, moral, individual, collective, and diffused damages.

By establishing in Brazil adequate standards of quality, safety, durability, and performance of products and services (Article 4, II, d, CDC), the Consumer Defense Code stipulated clear criteria for the resolution of consumption problems. For example, it guarantees the suppliers a 30-day period to remedy the defect (Article $18, \S 1, \mathrm{CDC})$, applicable when it is not an essential product and where replacement of the defective parts does not affect quality and characteristics of the product do not diminish the value. 
The National Consumer Relations Policy seeks to harmonize the interests of the participants in the relations based on good faith and equilibrium and assigns the consumer the basic rights to effective prevention and compensation of damages. Therefore, the equilibrium between parties in consumer relations also includes the regard to the fair distribution of "time investments".

The nature and role of mass culture ignores the individual as they seek to mold him/her into a preformatted role, disregarding its particular characteristics. The mass offer of products and services, although apparently personalized, actually follows the same itinerary. As Edgar Morin (1997) taught, "technology transforms relationships between men and relations between man and the world; it objectifies, rationalizes, depersonalizes" (p. 171). This context predominates a culture of disregard of personal interests in favor of increasing profits and market results (sometimes even against the law), and consumer disregard is observed when suppliers ignore the complaints or do not provide adequate, clear, and timely information, either by excessive standardization of the service model or by the lack of investments in the expansion and qualification of the consumer services.

The Brazilian Superior Court of Justice (STJ) has already shown clear signs of its concern with consumer's time when deciding, for example, that "it constitutes moral damages, susceptible to compensation, when the consumer of a new vehicle needs to return to the concessionaire several times for repair of defects presented on the vehicle purchased"1. Also, in February 2018, when revisiting the subject of the responsibility of the merchant to provide technical assistance services, the same court recognized his/her duty to "actively participate in the repair process, mediating the relationship between consumer and manufacturer" ${ }^{2}$. The reason is that the merchant, unlike the consumer, usually has a direct relationship with the manufacturer or his/her legal representative.

The court weighed the time lost by the consumer to locate the technical assistance close to his/her residence or place of work or even from where they purchased the product; and also the effort to schedule a "visit", as well as its part of the risk of the merchant's activity to use of "faster and more efficient solutions". It was pointed out in the judgment that in a large city, such as Rio de Janeiro, it is possible for a consumer to travel more than 30 kilometers to take a defective product to its technical assistance, a commercial practice that is regrettably repeated in large urban centers. It recognizes that it is unreasonable to add to the frustration of the consumer who has acquired a defective product all the annoyance and the time lost trying to solve himself/herself, the problem caused by the supplier. The merchant, therefore, must actively participate in the repair process by contacting the manufacturer or his/her legal representative.

In February 2019, it was published the first collegiate decision of the Superior Court of Justice expressly referring to the "theory of lost time". It recognized that

the duty of quality, safety, durability and performance that is attributed to suppliers of products and services by Art. 4 ,

II, $\mathrm{d}$ of the CDC has an implicit collective content, a social function, related to the optimization and maximum utilization of productive resources available in society, including time.

It establishes that

voluntary disrespect of legal guarantees, with the clear intention of optimizing profit in detriment of quality of service, reveals an offense to the duties attached to the principle of good-faith and configures an unfair and intolerable injury to the

\footnotetext{
${ }^{1}$ BRAZIL. Superior Court of Justice. Case AgInt no AREsp 821.945/PI, Justice Marco Aurélio Bellizze, 23/06/2016, published in 01/07/2016.

${ }^{2}$ BRAZIL. Superior Court of Justice. Case REsp 1634851/RJ, Justice Nancy Andrighi, 12/09/2017, published in 15/02/2018.
} 
social function of productive activity and protection of consumer time. ${ }^{3}$

The case concerned the violation of the municipal and state laws that stipulates a limit of time a consumer should be kept waiting in bank lines (usually around 20 minutes). Justice Nancy Andrighi recognized in her written arguments that the "maximum use of time" is a collective interest protected by the legal system and that "unfair and intolerable loss of consumer time", which occurs "for the voluntary disregard of legal guarantees...with the clear intention of optimizing profit to the detriment of the quality of the service". The court members recognized it constitutes an "offense to the duties annexed to the principle of good faith" and determined the payment of collective moral damages. In this case, it was also considered that the violation of the quality of service obligations imposed by the law "infringes essential values of society and has...the attributes of gravity and intolerability, and does not constitute mere violation of law or contract". This is the first collegial decision of a Superior Court "Turma" expressly acknowledging the appropriateness of the "Theory of Lost Time", which means consumers have a right to redress due to abusive loss of time caused by supplier's misconducts.

It should also be noted that damage due to lost time may imply patrimonial repercussions (for example, a professional who fails to provide remunerated assistance to a client because he/she is diverted from his/her productive activity to solve a consumption problem ${ }^{5}$ ) or moral damages, when the consumer is deprived of the freedom to enjoy his/her life as he might prefer. It is also admitted that the same situation of lost time may configure these two modes of damages cumulatively. It is the case of the liberal professional who, in addition to losing the commitment of work, not receiving its income, has its image blurred with the client that was not attended to.

It is natural and expected that problems arise in a few consumer relations, but in such cases the consumer cannot be compelled to bear alone-at the expense of his/her lifetime-all negative contingencies. Suppliers must find ways to resolve possible problems and conflicts in an agile and effective manner and, if this is not the case, it is their duty to redress the damages caused to the consumer whose time was improperly wasted. On the other hand, since compensation for moral damages is not meant to comfort the mishaps of common life, the suppliers conduct must be properly analyzed by reasonable criteria.

\section{Planned Disregard: Analyzing Supplier's Conduct Regarding Consumer’s Time}

For the characterization of the obligation to indemnify consumer's lost time, it is necessary to make a weighing judgment, analyzing the current legislation, the actual circumstances and, mainly, the conduct of the supplier.

Some suppliers impose to consumers a via crucis to solve problems regarding defective products or services, which we call "planned disregard". In spite of the high standards established by the legislation, what is

\footnotetext{
${ }^{3}$ BRAZIL. Superior Court of Justice. Case. REsp 1737412/SE, Justice Nancy Andrighi, 05/02/2019, published in 08/02/2019.

4 The São Paulo State Court of Justice, among others, admits the configuration of moral damage due to the time lost by the citizen in the search, without success, for the resolution of a consumption conflict. It is by them called "Theory of Lost Time". It considers that "cannot seem reasonable, in a minimally organized society, which lives in the incessant search for the optimization of its precious time, that a company can, with impunity, perform an undue charge and not solve the question of administrative way, causing the citizen to be compelled to move the Judiciary to get rid of something that he did not hire" (BRAZIL. São Paulo State Court of Justice. Case $\mathrm{n}^{\mathrm{o}}$ 1043696-86.2017.8.26.0224. L. G. Costa Wagner. Guarulhos. 34 ${ }^{\mathrm{a}}$ Câmara de Direito Privado. 17/09/2018, published in 17/09/2018).

${ }_{5}^{5}$ In Brazil, a professional may also be considered a consumer. Also, the definition of consumer contemplates natural persons and legal entities (Article 2nd, Consumer Defense Code).
} 
observed in numerous situations, it is an abuse of the supplier's right, who seeks to fully transfer to the consumer the burden of his/her economic activity. For example, in a daily basis, numerous infractions to the Decree that establishes standards for costumer services (Decree No. 6.523/2008) occur in Brazil and many of them are related to the resolution of consumer problems in a reasonable time. Planned disregard for legal safeguards also appears when the time taken by the supplier to present a solution is disproportionate in relation to its complexity.

The effect of this practice is perverse in the markets. Frequently, consumers simply give up claiming rights resulting from unsuccessful hires in the face of huge barriers to contacting suppliers. ${ }^{6}$ By weighing the costs and the benefit of the time and effort required to solve the problem faced, the consumer sometimes gives up the unmet demand. And in making the choice of valuing its own time, the consumer assumes a property loss that would compete with the supplier that is a risk inherent to his/her own economic activity. At some point, the "comings and goings" of the consumer go beyond the limit of reasonable, justifying the deferral of the indemnity payment for lost time. This evaluation is necessarily casuistic and should be based on the rules of experience.

In order to measure the damage caused by lost time in consumer relations, particularly the non-financial damages resulting from consumer's lost time, we propose the application of a double criteria.

First, it is proposed to identify in the particular case the disregard: The consumer or his/her demand were disrespected or disregarded by the supplier. Consumer disregard is observed in the cases of suppliers who ignore consumer requests and complaints or do not provide adequate, clear, and timely information. Disregard is disrespect, devaluation of the importance of one's request.

The second criteria is planning: Could the supplier of products or services have spared consumer time by the implementation of mechanisms to increase contract security? There are damages that cannot be avoided. However, the conduct of the contractor who is responsible for them should influence the limits of the duty to repair. The second factor for the characterization of the duty to compensate for consumer lost time-planning - is characterized by the absence of adequate, agile, effective, and efficient mechanisms to solve consumer demands. Investments in the production chain are always planned, controlled by the supplier. And the lack of investment is also planned (Marques, 2011). ${ }^{7}$

If the answer is affirmative to both questions, therefore, if the consumer was disregarded, he/she had his/her legitimate expectation frustrated, and the supplier could have avoided the loss of consumer time by implementing mechanisms to increase security or the agility of contracting, the supplier is charged with responsibility for the time unduly lost by the consumer waiting for a resolution to his/her demand.

In order to assess, in the specific case, if the supplier fulfills the legal duties of adequate service to consumers, it is recommended to observe, among other actual circumstances:

(a) The prior implementation of concrete measures for the prevention of damages to consumers, compatible with the size of the company;

(b) The existence of channels and means to receive and register the complaint that is appropriate to the

\footnotetext{
${ }^{6}$ The realistic alternative to a class action is not 17 million individual suits, but zero individual suits, as only a lunatic or a fanatic sues for \$30 (Carnegie v. Household Intl. Inc., 376 F.3d 656, 661 [CA7 2004], http://caselaw.findlaw.com/us-7th-circuit/1296172.html, 4 Mar. 2019).

7 As we noted before, among the differences between consumer time and supplier time is the finding that "the 'loss' or time deviation of the supplier is valued as an economic cost or burden".
} 
target public of the supplier in question and the voluntary adherence to alternative dispute resolution programs;

(c) The investments made in structure and employees training in order to meet the demands of consumers, in proportion compatible with the performance of the company;

(d) The waiting time for customer service that has a claim or complaint, as well as whether or not there has been a violation of the criteria established by law or by the regulatory agencies;

(e) The response time of the supplier in the specific case, analyzing mainly the proportionality between the degree of difficulty of the diligence and the time used by the supplier until the definitive resolution of the problem;

(f) The occurrence of extreme situations, natural disasters, or other disasters, which are not confused with the risks of the activity, but made the delivery or response delay inevitable.

The disregard for consumer's time is not a tolerable nuisance; the application for compensation for wrongfully lost time is not "frivolous litigation" but rather a reaction to abusive and planned commercial strategy of disobedience to quality standards imposed by legislation to maximize profit and results. It operates with the system failures, such as the lack of supervision and the enormous difficulties imposed on consumers to seek the effectiveness of their rights. Planned disregard makes small damages to consumers become great gains for suppliers. And with this type of strategy, the judiciary cannot be conniving.

The attitude of suppliers causing excessive delay in customer services and problems-solving cannot be awarded with the conclusion it generates merely a discomfort or an annoyance that does not motivate the duty to compensate consumer individually. Compensation for moral damages in this case-considering the legal barriers to punitive damages in Brazil-is not a distortion of the purpose of the institute, nor generates unjust enrichment to the consumer (since he was indeed a victim of poor service delivery), but serve as remedy for breach of statutory warranty obligations and quality standards imposed by the CDC.

Disregard lies in devaluation, disrespect, lack of consideration, disproportional time-consuming efforts within a consumer legal relationship at any stage, whether to resolve a product or service defect or to understand inadequately presented technical instructions, for example. If the consumer was disregarded, disrespected, if he/she had his/her legitimate expectation of good service unattended, and the supplier could have avoided the damage by implementing mechanisms to increase security or agility in service, but incurred in "voluntary disrespect of legal guarantees", the supplier's liability must be recognized.

On the other hand, this will not be the case if the supplier is able to prove the impact of one of the exclusions of responsibility set forth in Articles $12, \S 3$, and 14, §3, of CDC. For example, although there may have been an unexpected delay in fulfilling the consumer's request, there was no lack of diligence or attention by the supplier to the timely demand. If there was not another possible conduct for the supplier in the specific case, due to the proven lack of mechanisms to improve service in that circumstance, the supplier failure to fulfill his/her legal obligations will not be characterized. Examples include natural or other disasters, massive landslides, or major floods with damage to residential and commercial units-in such situations the delay is inevitable and gives rise to the exclusion of responsibility for unreliable conduct of the supplier. It is clear in these situations that the delay was not caused by any abusive commercial practice or strategy.

The focus of this methodology lays not only in the value and quantification of "consumer time", but in the scheduling, planning and the control exercised by suppliers that allows them not to perform, in good faith, their duties to prevent and fully redress damages to consumers (grounds for the obligation to redress, "Haftungsgrundlage" [Marques, 2019]). It is necessary to overcome the culture of disregard for "the time of the 
other" to initiate a new cycle of respect for the essential and existential interests of vulnerable agents in the markets through the evolution of commercial practices.

It must be remembered that the "rules of the game are not to end it, but to allow it to develop, considering the movement of all those involved" (Bolzan de Morais, 1998, p. 83) and that investments in quality and proper services reverts in good standing and customer loyalty, something that the best companies in the markets realized a long time ago. The case law formed in favor of guaranteeing products and services with adequate standards of quality, safety, durability, and performance-as provided in Art. 4, II, d of the CDC-contributes to the incorporation of the role of Consumer Law in business behavior.

\section{Structural Injunctions to Prevent Consumer's Time Loss}

It is also known that individual redress is not enough to put many profitable and illegal strategies to rest. Apart from criminal prosecution, another possible response to those actions is the structural injunctions. Members of the National Consumer Protection System, such as the regulatory agencies, civil entities, and the judiciary may contribute to the prevention of undue loss of consumer time by promoting structural processes.

One of the biggest challenges of class actions in Brazil is the problem related to the generic decisions that, in practice, correspond to several individual actions added together. Another possible direction, in order to offer to the judges "new patterns of performance and, above all, larger flexibility in the adaptation of his decision to do what demands the concrete situation" (Arenhart, 2013, pp. 389-410), is the adoption of structural decisions as suggests the North-American doctrine (Fiss, 1978). The structural injunctions, prophylactic injunction, or institutional remedies constitute an important instrument for the obtaining of better results.

The main objection to the structural decisions is the claim that through it the judiciary would be usurping functions that originally belonged to the executive and legislative, thus violating the principle of separation of the three powers (on other words, being undemocratic). However, as Owen Fiss (2017) argued, "this objection overlooks the multi-dimensional nature of the judge's authority and, in fact, his duty", since "the judge must not only decide the rights of the plaintiff, but also make this right a practical reality" (p. 596).

Structural injunctions may contribute to prevent consumer's time loss. More important than to redress is to avoid damages. In the context of consumer relations, it is possible to impose progressive changes of conducts on the suppliers by determining, for example, progressive investments in customer care services or changing some service habits. The need to make the constitutional guarantee of consumer protection a "living truth" requires a vigorous intervention in the consumer market, not only after the occurrence of the damage, as a remedy, but mainly before its occurrence, determining the implementation of preventive measures.

There is also legal support for such initiatives in Article 83 of the CDC, according to which, "in order to defend the rights and interests protected by this Code, all sorts of actions capable and enforcing it are permissible", supplemented by the following article (Article 84, CDC) that authorizes the judge to grant the "measures that will ensure a practical resolution for the damage caused". The intention of the legislator in the drafting of these provisions was precisely to establish the principle of effective and proper legal protection of all the rights enshrined in the code (Watanabe, 2007).

Structural injunctions may be the game changer to prevent consumer's loss of time by analyzing supplier's conduct. The structural process is guided towards the future instead of only the approach that led to the plea. It is appropriate when the complexity of the demand requires a broader view of the context, when it demands the implementation of a global reform to prevent new litigation or when it is not adequately satisfied only with the 
arbitration of an indemnity. Well-constructed judicial decisions can serve suppliers as a mapping of the failures that need correction in their business, including the planned disregard for consumer's time. The individualization of each type of damage in the construction of the indemnity value, for example, can contribute significantly to the prevention of new damages, since the offender would have real conditions to invest in the restructuring of his productive chain in order to avoid the repetition of one or more of the errors pointed out by the judge. As we noted before, damage prevention is much more important than redress, especially when it concerns consumer's time.

\section{Conclusion}

Consumer relations are constantly affected by our society's transformations and our periodical technological revolutions. The law-makers cannot keep up with it, at least not as fast as we would like them to do. However, innovation in consumer law also means to be aware of those changes and to rethink the way we interpret and apply the existing law, especially if Congress does not change a single word of it.

In a society that values time immensely, consumer's right to full redress must also contemplate the time unfairly lost. The right to products and services of quality must also consider the guarantee of proper and timely response in case of defect. And the denial of a fair treatment by the supplier, forcing the consumer to seek judicial interference, must be replied with the guarantee of compensation for the lost time, at least.

It cannot be worth to injure several people and responding only to the few who have access to the judiciary. It is fundamental avoid mass damages and avoid litigation with exemplary sanctions from those who seek to preserve this unbearable system of repeated non-compliance with the legal duties of conduct. At the end of the day, it must not be more profitable for suppliers to ignore consumer rights than to fulfill them.

It is necessary to construct a new and equitable distribution of time in consumer relations, to restore to consumer the control of his/her own time, to make him/her the protagonist of his/herown history. Above all, we must not surrender to the "tyranny of quantifiable". We shall overcome this obstacle, the wrong perception that compensation should be denied because it is not possible to establish, with reasonable accuracy, the (economic-financial) value of lost time.

\section{References}

Arenhart, S. C. (2013). Decisões estruturais no direito processual civil brasileiro. Revista de Processo, 225, 389-410.

Bergstein, L. (2019). O tempo do consumidor e o menosprezo planejado: O tratamento jurídico do tempo perdido e a superação das suas causas. São Paulo: Revista dos Tribunais/Thompson Reuters.

Bolzan de Morais, J. L. (1998). A subjetividade do tempo: Uma perspectiva transdisciplinar do direito e da democracia. Porto Alegre: Livraria do Advogado.

Fiss, O. M. (1978). The civil rights injunction. Indiana: Indiana University Press.

Fiss, O. M. (2017). To make the constitution a living truth: Four lectures on the structural injunction. In S. C. Arenhart and M. F. Jobim (Eds.), Processos estruturais (p. 596). Salvador: Juspodivum.

Frisch, D. (2012). It's about time. Tennessee Law Review, 79, 757-801.

Ghersi, C. A. (2000). Valuación económica del dano moral y psicológico-Dano à la psiquis. Buenos Aires: Astrea.

Grinover, A. P., Benjamin, A. H., Fink, D. R., Filomeno, J. G. B., Watanabe, K., Júnior, N. N., \& Denari, Z. (2007). CDC commented by the authors of its draft (9th ed.). Rio de Janeiro: Forense Universitária.

Hawking, S. W. (1992). Uma breve história do tempo: Do big bang aos buracos negros. Rio de Janeiro: Rocco.

Hawking, S. W. (2002). O universo numa casca de noz (5th ed.). São Paulo: Arx.

Lamb, C. (2008). The life, letters and writings of Charles Lamb: Correspondence with manning. New York: Cosimo Classics. 
Marques, C. L. (2011). Prefácio. In M. Dessaune (Ed.), Desvio produtivo do consumidor: O prejuizo do tempo desperdiçado (pp. 11-12). São Paulo: Revista dos Tribunais.

Marques, C. L. (2019). Presentation. In L. Bergstein (Ed.), O tempo do consumidor e o menosprezo planejado: O tratamento jurídico do tempo perdido e a superação das suas causas. São Paulo: Revista dos Tribunais.

Marques, C. L., \& Bergstein, L. (2018). A valorização e a tutela do tempo do consumidor: A nova posição do STJ sobre responsabilidade do comerciante por vícios. Revista dos Tribunais, 997, 211-226.

Marques, C. L., \& Miragem, B. (2014). O novo direito privado e a proteção dos vulneráveis (2nd ed.). São Paulo: Revista dos Tribunais.

Morin, E. (1997). Cultura de massas no Século XX: Espírito do tempo 1-neurose (9th ed.). Tradução: Maria Ribeiro Sardinha. Rio de Janeiro: Forense Universitária.

Solnit, R. (2004). River of shadows: Eadweard Muybridge and the technological wild west. New York: Penguin Books.

Watanabe, K. (2007). Comments to Art. 83 of CDC. In A. P. Grinover et al. (Eds.), CDC commented by the authors of its draft (9th ed., p. 854). Rio de Janeiro: Forense Universitária. 